\title{
Upaya Strategis Pemerintah Kota Surakarta dalam Mewujudkan Profesionalisme Sumber Daya Manusia Aparatur
}

\author{
Henny Juliani \\ Fakultas Hukum Universitas Diponegoro \\ Email: hennyjuliani.fhundip@gmail.com
}

\begin{abstract}
Professionalism of human resources of public servants in executing public service tasks, governmental tasks, and specific development tasks are often percepted with bad stigma particularly in negative issues on quality and performance aspect. Based on this fact, Government of Surakarta Municipality perform strategic efforts in improving professionalism of human resources of public servants in order to their quality and performance will increase as well as can realizing prime services to citizen. This research use empirical juridical approach. Whilst specification of the research is analytical descriptive, and source of data comprises of primary and secondary data. The result of research was analyzed quantitatively. Based on the research, it can be conclude that in improving professionalism of human resources of public servants, Government of Surakarta Municipality perform strategic efforts, namely: 1. Fulfilling demand of number of human resources of public servants with specific qualification, 2. Improving capacity and quality of human resources of public servants that relevant to improve their competency, 3. Applying e-Performance as a system to evaluate performance of human resources of public servants in manage personal work load as well as organization, performance indicator achievement as a basic calculation of work achievement and incentive reward, 4. Applying discipline penalty in accordance to behavior of human resources of public servants. Strategic efforts of Government of Surakarta Municipality complied with regulation of PerMenPan dan RB No.38 Year 2018 regarding Measurement of Professionalism of Human Resources of Public Servants which is measured by using 4 (four) dimension, comprises of: a. qualification, b. competence, c. performance, and d. discipline.
\end{abstract}

Keywords: Public Servants, Government Of Surakarta Municipality

\begin{abstract}
Abstrak
Penelitian ini bertujuan untuk mengetahui upaya strategis pemerintah Kota Surakarta dalam mewujudkan profesionalisme sumber daya manusia aparatur. Penelitian ini menggunakan metode pendekatan yuridis empiris. Adapun spesifikasi penelitian adalah deskriptif analitis, dengan sumber data yang diperoleh secara primer dan sekunder. Hasil penelitian selanjutnya akan dianalisis secara kualitatif. Berdasarkan hasil penelitian, maka dapat diketahui bahwa dalam meningkatkan profesionalisme SDM Aparatur, Pemerintah Kota Surakarta melakukan upaya strategis yang berupa: 1. Pemenuhan kebutuhan jumlah SDM Aparatur dengan kualifikasi tertentu, 2. Peningkatan kapasitas dan kualitas SDM Aparatur, yang berkaitan dengan peningkatan kompetensi, 3. Penerapan E-Kinerja sebagai sistem penilaian kinerja SDM Aparatur dalam mengelola beban kerja personil maupun organisasi, capaian indikator kinerja sebagai dasar perhitungan prestasi kerja serta pemberian insentif kerja, 4. Penerapan hukuman disiplin yang berkaitan dengan perilaku kerja SDM Aparatur. Upaya strategis yang dilakukan oleh Pemerintah Kota Surakarta tersebut sudah sejalan dengan ketentuan PerMenPan dan RB Nomor 38 Tahun 2018 tentang Pengukuran Indeks Profesionalitas Aparatur Sipil Negara, yang diukur dengan menggunakan 4 (empat) dimensi, meliputi: a. Kualifikasi, b. Kompetensi, c. Kinerja, dan d. Disiplin.
\end{abstract}

Kata kunci: Aparatur Sipil Negara, Pemerintah Kota Surakarta 


\section{A. Pendahuluan}

Undang-Undang Nomor 5 Tahun 2014 tentang Aparatur Sipil Negara menyatakan bahwa Aparatur Sipil Negara (ASN) sebagai profesi berlandaskan pada prinsip nilai dasar; kode etik dan kode perilaku; komitmen, integritas moral, dan tanggung jawab pada pelayanan publik; kompetensi yang diperlukan sesuai dengan bidang tugas; kualifikasi akademik; jaminan perlindungan hukum dalam melaksanakan tugas; dan profesionalitas jabatan. Di masyarakat masih terdapat keluhan tentang profesionalitas ASN sebagai SDM aparatur dalam penyediaan layanan. Tuntutan profesionalitas ASN mengemuka karena tingkat kepuasan masyarakat sebagai pengguna layanan memandang bahwa profesionaltas ASN masih rendah bahkan banyak masalah ditemukan berkaitan dengan pelaksanaan tugas dan fungsi ASN.

Masalah integritas ASN dapat dilihat dari banyaknya perilaku menyimpang seperti Korupsi, Kolusi dan Nepotisme (KKN) yang dilakukan oleh pegawai ASN. Masalah kompetensi dapat dilihat dari tingkat pendidikan mayoritas pegawai ASN yang masih rendah, Menpan RB mencatat bahwa dari 4.475.997 PNS ASN $64 \%$ di antaranya hanya bekerja sebagai pegawai administrasi. Masalah kinerja ASN dapat dilihat dari output yang menunjukkan masih banyak masyarakat mengeluhkan atas lambatnya pelayanan publik. Masalah disiplin dapat dilihat dari masih adanya perbuatan pegawai ASN yang melanggar peraturan dan ketentuan yang berlaku misalnya tentang netralitas PNS. ${ }^{1}$ Pemetaan Indonesian Corruption Watch menempatkan ASN sebagai aktor yang paling banyak terjerat kasus korupsi pada semester I 2018.Terdapat 10 kasus korupsi berdasarkan aktor yang melakukan, yakni ASN sebanyak 101 orang, ketua atau anggota DPRD sebanyak 68 orang, pihak swasta sebanyak 61 orang Selanjutnya kepala desa sebanyak 29 orang, kepala daerah 22 orang, pejabat pengadaan 19 orang, aparatur desa sejumlah 11 orang, masyarakat sebanyak 6 orang, serta ketua atau anggota kelompok atau organisasi sejumlah 6 orang. ${ }^{2}$ Data tersebut menunjukkan bahwa ASN sebagai suatu profesi bagi PNS maupun PPPK yang bekerja pada instansi pemerintah belum mampu mewujudkan profesionalitas dalam melaksanakan tugas dan fungsinya.

Dalam menjalankan fungsi pemerintahan dan pembangunan, Pemerintah Kota Surakarta didukung oleh 6294 orang PNS, 2059 orang Tenaga Kerja dengan Perjanjian Kerja (TKPK), dan 509 orang pegawai honorer K-2. SDM inilah yang akan menjalankan fungsi sebagai pelaksana kebijakan publik, pelayan publik, perekat dan pemersatu bangsa. Oleh karena itu diperlukan langkah strategis membangun SDM aparatur melalui upayaupaya peningkatan profesionalisme agar tata kelola pemerintahan yang baik (good governance) dapat terwujud dan masyarakat yang dilayani dapat merasakan dampak dari pelayanan yang lebih baik. Penelitian yang dilakukan ini ingin mengetahui upaya strategis

1 Ajib Rakhmawanto, Mengukur Indeks Profesionalitas ASN: Analisis Tujuan dan Kemanfaatan, Jurnal Policy Brief Nomor: 006-April 2017 ISSN: 2541-4267.

2 Kompas.com, Selasa 18 September 2018 
Pemerintah Kota Surakarta dalam meningkatkan profesionalitas SDM Aparatur sehingga dapat menunjang pelaksanaan tugas dan fungsi ASN dalam memberikan pelayanan publik yang lebih baik dan memuaskan masyarakat.

\section{Metode Penelitian}

Metode pendekatan yang digunakan dalam penelitian ini adalah metode yuridis empiris, karena masalah yang akan diteliti berhubungan erat dengan law in action. Metode pendekatan ini digunakan untuk menganalisa hukum bukan semata-mata sebagai suatu seperangkat aturan perundang-undangan yang bersifat normatif belaka, akan tetapi hukum dilihat sebagai perilaku masyarakat, selalu berinteraksi dan berhubungan dengan aspek kemasyarakatan seperti politik, ekonomi, sosial, dan budaya.

Spesifikasi penelitian yang digunakan adalah deskriptif analitis, untuk menggambarkan hasil yang diperoleh dari penelitian ini secara rinci, sistematis dan menyeluruh mengenai sesuatu yang berkaitan dengan peraturan perundang-undangan yang berlaku dikaitkan pula dengan teori-teori hukum yang mendukung penyelesaian permasalahan untuk selanjutnya dilakukan analisa secara kritis terhadap permasalahan tersebut. Penelitian ini menggunakan data primer dan data sekunder. Cara untuk menarik kesimpulan dari hasil penelitian menggunakan metode induktif, yaitu suatu cara penelitian yang berangkat dari fakta-fakta yang ditemukan di lapangan kemudian dianalisis dengan konsep-konsep teori yang digunakan dalam penelitian. ${ }^{3}$

\section{Kerangka Teori}

Berdasarkan ketentuan Pasal 1 ayat (3) UUD 1945, "Negara Indonesia adalah negara hukum.” Sebagai negara hukum, maka setiap penyelenggaraan urusan pemerintahan haruslah berdasarkan pada hukum yang berlaku. Indonesia sebagai negara hukum memenuhi konsep yang dikemukakan oleh F.R. Bothlingk sebagaimana dikutip oleh Ridwan H.R. adalah "De staat, waarin dewilsvrijheid van gezagsdragers is beperkt door grenzen van recht" (negara, dimana kebebasan kehendak pemegang kekuasaan dibatasi oleh ketentuan hukum). A. Hamid S. Attamimi, dengan mengutip Burkens, mengatakan bahwa negara hukum (rechtsstaat) secara sederhana adalah negara yang menempatkan hukum sebagai dasar kekuasaan negara dan penyelenggaraan kekuasaan tersebut dalam segala bentuknya dilakukan di bawah kekuasaan hukum. ${ }^{4}$ Sehingga dapat dikatakan bahwa dalam suatu negara hukum, semua harus tunduk kepada hukum secara sama, yakni tunduk kepada hukum yang adil. Tidak ada seorangpun termasuk penguasa negara yang kebal terhadap hukum ${ }^{5}$.

Sebagai negara hukum dalam penyelenggaraan negara diperlukan adanya pegawai ASN yang diberi tugas untuk melaksanakan tugas pelayanan publik, tugas pemerintahan,

3 Sudarwan Denim, Menjadi Peneliti Kualitatif, (Bandung: Pustaka Setia, 2002), halaman 62

4 Ridwan H.R. Hukum Administrasi Negara, (Jakarta: P.T. Raja Grafindo Persada, 2014), halaman 21.

5 Munir Fuadi, Teori Negara Hukum Modern (Rechtstaat), (Bandung: P.T. Refika Aditama, 2009), halaman 2. 
dan tugas pembangunan tertentu. Pengaturan tentang pegawai ASN masuk dalam lingkup hukum kepegawaian.

Menurut S.F. Marbun dan Moh. Mahfud M.D., Hukum kepegawaian yang dipelajari dalam Hukum Administrasi Negara adalah hukum yang berlaku bagi pegawai yang bekerja pada administrasi negara sebagai pegawai negeri. Hukum mengenai subyek hukum (persoon) dalam lapangan administrasi negara yang dalam status kepegawaian itu mereka mempunyai hubungan dinas publik $^{6}$. Yang dimaksud hubungan dinas publik menurut Logemann adalah bilamana seseorang mengikat dirinya untuk tunduk pada perintah dari pemerintah untuk melakukan sesuatu atau beberapa macam jabatan yang dalam melakukan sesuatu atau beberapa macam jabatan itu dihargai dengan pemberian gaji dan beberapa keuntungan lain ${ }^{7}$. Oleh karena itu dalam menjalankan hubungan dinas publik sangat diperlukan adanya birokrasi yang akan menunjang kinerja pemerintahan tersebut.

Birokrasi adalah kata yang lekat dengan mesin kerja pemerintah. Di Indonesia jumlah birokrat sebanyak 4,7 juta memang belum memadai atau sebanding dengan jumlah masyarakat yang dilayani yang mencapai angka 270 jutaan penduduk. Namun masalah ini tentunya bukan isu utama sebab apabila secara kuantitas pegawai negeri banyak belum berarti bahwa pelayanannya akan maksimal. Permasalahan sesungguhnya disebabkan sebaran birokrat yang tidak merata ke seluruh wilayah tanah air dan tentunya kesenjangan kompetensi aparatur yang inheren dengan problem dasar kinerja organisasi pemerintah yang belum optimal. ${ }^{8}$

Menurut Peter M. Blau dan Marshall W. Meyer, "Birokrasi" dalam pengertian sehari-harinya diidentikkan dengan ketidakefisienan (inefficiency) atau "benang merah" dalam pemerintahan; arti yang sebenarnya tidaklah demikian. Satu hal yang cukup menarik adalah bahwa birokrasi selain sering diartikan sama dengan ketidakefisienan, dalam keadaan-keadaan tertentu diartikan pula sebagai efisiensi yang ketat (ruthless efficiency). ${ }^{9}$

Max Weber sebagaimana dikutip oleh Amy Y.S. Rahayu dan Vishnu Yuwono mengidentifikasikan beberapa karakteristik dari sebuah birokrasi yang menurut dia ideal yang secara profesional dan rasional dijalankan. Karakteristik tersebut di antaranya sebagai sebuah sistem administrasi publik yang rasional berdasarkan aturan tertulis, dikelola secara impersonal dan dengan pembagian tugas yang jelas. Para birokrat yang dipilih untuk jabatan pimpinan berdasarkan tingkat kompetensi, bukan kolusi. Selain itu

6 S.F. Marbun dan Moh. Mahfud M.D., Pokok-pokok Hukum Administrasi Negara, (Yogyakarta: Liberty, 1987), halaman 97

Ibid, halaman 98

8 Kristian Widya Wicaksono, Telaah Kritis Administrasi \& Manajemen Sektor Publik di Indonesia, (Yogyakarta: Penerbit Gava Media, 2014), halaman 51

9 Peter M. Blau dan Marshall W. Meyer, diterjemahkan oleh Gary R. Jusuf, Birokrasi dalam Masyarakat Modern, (Jakarta: UI Press, tanpa tahun), halaman 3-4 
Weber juga menekankan pentingnya pendidikan dan birokrat seharusnya merupakan sebuah profesi dengan tingkat keahlian yang tinggi. Sehingga Weber berkesimpulan bahwa birokrasi terdiri dari struktur yang hierarkis, namun profesional, taat kepada sistem hukum, bersifat impersonal, menganut sistem meritokrasi, yang terdiri dari para aparatur negara dengan sebuah keahlian tertentu. ${ }^{10}$

Kebijakan reformasi birokrasi dalam mengelola sumber daya aparatur dapat dilakukan dengan tahapan sebagai berikut: ${ }^{11}$

1) Menata dan reformasi organisasi, yaitu redefinisi Visi, Misi, Tata Laksana (proses bisnis).

2) Menyusun direktori kompetensi didasarkan pada tugas dan fungsi organisasi atau lembaga.

3) Menyusun Standar Kebutuhan Kompetensi Jabatan.

4) Melakukan Penilaian Kompetensi Pegawai.

5) Penggunaan hasil pengukuran kompetensi jabatan dan penilaian kompetensi pegawai dalam melaksanakan fungsi-fungsi manajemen kepegawaian seperti pengadaan pegawai, penilaian kinerja, perencanaan karir, penempatan, pelatihan, pemberian insentif, dan sebagainya.

Profesionalisme pegawai dalam sebuah organisasi sangat ditentukan oleh tingkat kemampuan yang tercermin melalui perilaku sehari-hari. Kemampuan menunjukkan potensi dalam melaksanakan tugas yang mungkin dan tidak mungkin dilakukan. Sedangkan profesional dalam pendekatan sistem merit mengandung persyaratan kompetensi (pengetahuan, keahlian, pengalaman), kualifikasi (pendidikan, pelatihan), kinerja (target, pencapaian), kompensasi (kebutuhan, external equity) dan disiplin. Berdasarkan hal tersebut, maka indikator yang digunakan dalam mengukur indeks profesionalitas ASN menurut Sutiadi sebagaimana dikutip oleh Ajib Rakhmawanto adalah kompetensi, kinerja, kompensasi, dan disiplin, dengan rumus matematis sebagai berikut: ${ }^{12}$

$$
\operatorname{IdxPro}=\operatorname{Koef}(1-\text { gaps })+\operatorname{Koef}(\operatorname{Kj})+\operatorname{Koef}(1-\delta
$$

SI(inex))+Koef(1-inDiscpl).

Keterangan:

Gaps $\quad$ : Persentase ASN yang tidak kompeten

10 Amy Y.S. Rahayu dan Vishnu Juwono, Birokrasi \& Governance Teori, Konsep, dan Aplikasinya, (Depok: Rajawali Pers, 2019), halaman 4-5

11 Dyah Kusumastuti, , https://www.researchgate.net/publication/316274009 Manajemen Sumber Daya Aparatur berbasis Kompetensi

12 Ajib Rakhmawanto, Op cit 


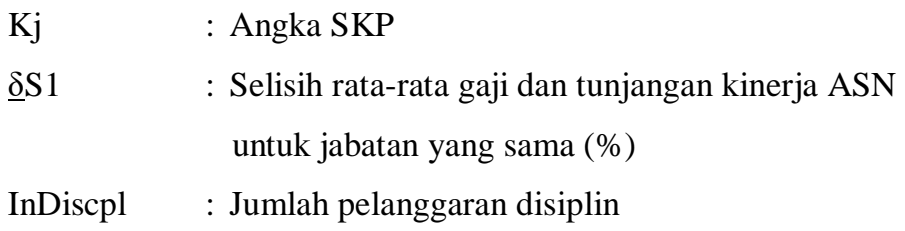

Gambar 1

Indeks Profesionalitas ASN

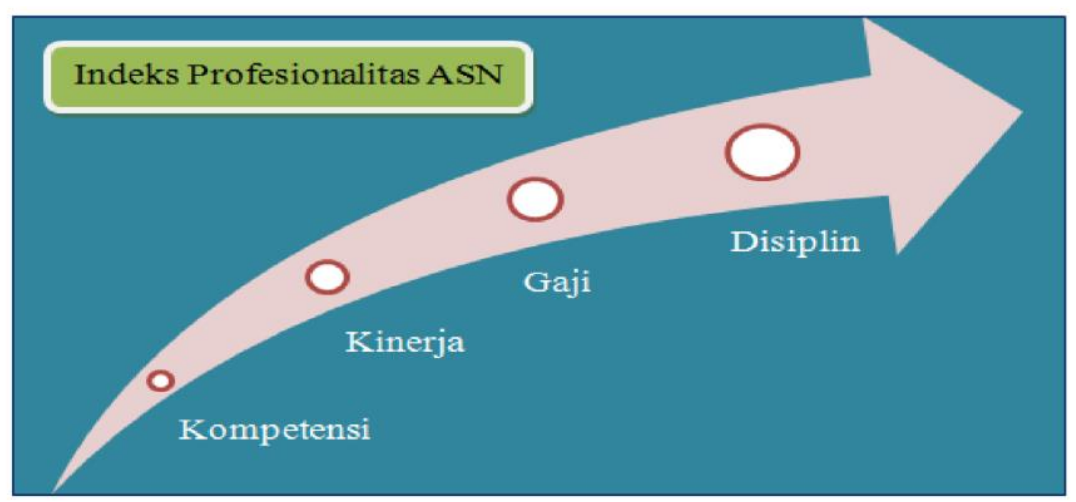

Sumber: Kementerian Riset, Teknologi, dan Pendidikan Tinggi, 2016

Dalam Peraturan Menpan dan RB Nomor 38 Tahun 2018 tentang Pengukuran Indeks Profesionalitas Aparatur Sipil Negara Pasal 4 dinyatakan bahwa Indeks Profesionalitas ASN diukur dengan menggunakan 4 (empat) dimensi, meliputi: Kualifikasi; Kompetensi; Kinerja; dan Disiplin.

Kualifikasi diukur dari indikator riwayat pendidikan formal terakhir yang telah dicapai, misalnya: pendidikan S-3, S-2, S-1, dan lain sebagainya. Kompetensi diukur dari indikator riwayat pengembangan kompetensi yang telah dilaksanakan, misalnya: diklat kepemimpinan, diklat fungsional, diklat teknis, dan seminar/workshop/konferensi/setara. Kinerja diukur dari indikator penilaian prestasi kerja PNS yang meliputi: sasaran kerja pegawai (SKP) dan perilaku kerja. Selanjutnya disiplin diukur dari indikator riwayat penjatuhan hukuman disiplin yang pernah dialami: tidak pernah dijatuhi hukuman disiplin atau pernah dijatuhi hukuman disiplin (ringan, sedang, berat). Ketentuan lebih lanjut tentang Pengukuran Indeks Profesionalitas ASN diatur dengan Peraturan Badan Kepegawaian Negara RI Nomor 8 Tahun 2019 tentang Pedoman Tata Cara dan Pelaksanaan Pengukuran Indeks Profesionalitas Aparatur Sipil Negara.

\section{B. Pembahasan}

Birokrasi dalam pemerintahan yang ideal adalah birokrasi yang profesional dan rasional yang bertujuan untuk mewujudkan tata kelola pemerintahan yang baik (good governance) melalui peningkatan profesionalitas SDM Aparatur. Oleh karena itu maka Pemerintah Kota Surakarta melakukan upaya-upaya dalam mewujudkan profesionalitas 
tersebut agar pegawai ASN Kota Surakarta memiliki integritas, kualifikasi, kompetensi, berkinerja baik dan disiplin dalam melaksanakan tugas jabatannya.

Strategi yang digunakan oleh Pemerintah Kota Surakarta dalam mewujudkan profesionalitas SDM aparatur dilakukan melalui 4 (empat) cara yaitu: ${ }^{13} 1$. Pemenuhan kebutuhan jumlah SDM; 2. Peningkatan kapasitas dan kualitas SDM; 3. Penerapan EKinerja; dan, 4. Penerapan hukuman disiplin.

\section{Ad.1. Pemenuhan kebutuhan jumlah SDM dilakukan melalui cara:}

a. Pemenuhan kebutuhan jumlah SDM dihitung berdasarkan analisis kebutuhan pegawai yaitu suatu metode untuk mengetahui jumlah pegawai di suatu unit organisasi yang dilakukan secara sistematis dengan menggunakan metode analisis beban kerja dan/atau metode lainnya serta membandingkan kebutuhan PNS dengan persediaan yang ada sehingga dapat diketahui kebutuhan riil pegawai. Hal ini mengacu pada Peraturan Kepala Badan Kepegawaian Negara Nomor 19 Tahun 2011 tentang Pedoman Umum Penyusunan Kebutuhan Pegawai Negeri Sipil.

Faktor-faktor yang dipertimbangkan dalam penghitungan kebutuhan PNS adalah: 1). Beban kerja; 2). Standar kemampuan rata-rata; 3). Waktu kerja; dan 4). Profil daerah, antara lain mencakup jumlah penduduk, kondisi geografis, potensi pengembangan daerah, dan kemampuan keuangan. ${ }^{14}$

Tindak lanjut dari analisis kebutuhan pegawai tersebut ditindaklanjuti oleh Pemerintah Kota Surakarta dengan menetapkan kompetensi, kuantitas dan kualitas pegawai. Penetapan jumlah pegawai dilakukan melalui:

a) Rekrutmen PNS tergantung formasi yang disediakan dan jumlah formasi yang diberikan oleh Pemerintah Pusat.

b) Proses mutasi PNS Pusat atau PNS Daerah (dari instansi lain) ke Pemerintah Kota Surakarta dipermudah dalam rangka pemenuhan SDM aparatur walaupun tetap melalui seleksi. Alasan yang banyak digunakan dalam mutasi tersebut adalah alasan keluarga.

c) Rekrutmen tenaga kontrak (Tenaga Kerja dengan Perjanjian Kerja/TKPK), berdasarkan Peraturan Walikota Surakarta Nomor 26-A Tahun 2016 tentang Pedoman Pengadaan Jasa Tenaga Kerja dengan Perjanjian Kerja di Lingkungan Pemerintah Kota Surakarta. TKPK tersebut merupakan produk diskresi daerah dengan standar gaji yang berbeda untuk masing-masing kualifikasi pendidikan, misalnya: SLTA sebesar Upah Minimum Kota (UMK), D3 sebesar maksimal 1,5 kali UMK dan S1 sebesar maksimal 2 kali UMK. Rekrutmen TKPK dilakukan

13 Dwi Ariyanto, wawancara, Sekretaris BKPPD Kota Surakarta, 14 November 2018

${ }^{14}$ Azhar, M., Ispriyarso, B., Sa'adah, N., Suharso, P., Juliani, H., Setyono, J., \& Suparmin, S. (2019). State revenue of the fishery sector after the prohibition policy on illegal unreported and unregulated fishing. In 4th International Conference on Tropical and Coastal Region Eco Development. IOP P Conf. Series: Earth and Environmental Science 246 (2019) 012083. Semarang. doi:10.1088/1755-1315/246/1/012083 
melalui seleksi terbuka sesuai dengan kebutuhan Pemerintah Kota Surakarta untuk menutup kekurangan 400 PNS yang telah pensiun. Sebagian besar (sekitar 200) TKPK berasal dari tenaga pendidik untuk menutup kekurangan guru PNS. Sampai bulan Oktober 2018 jumlah TKPK sebesar 2059 orang, sedangkan pegawai honorer K-2 berjumlah 509 orang.

Berdasarkan Undang-Undang Nomor 43 Tahun 1999 yang merupakan perubahan Undang-Undang Nomor 8 Tahun 1974 tentang Pokok-Pokok Kepegawaian dikenal adanya PNS dan pegawai tidak tetap. Ketentuan tersebut menjadi dasar pengangkatan pegawai tidak tetap/honorer/kontrak oleh pejabat pemerintahan dengan menggunakan kewenangan diskresi untuk dipekerjakan di instansi pemerintah. Diskresi yang digunakan oleh pejabat pemerintahan untuk mengangkat pegawai tidak tetap/honorer/kontrak tersebut dimaksudkan untuk memenuhi kebutuhan pegawai yang bersifat mendesak agar fungsi pemerintahan bisa berjalan, karena apabila berharap pada ketersediaan pegawai negeri maka pelaksanaan fungsi pemerintahan akan terhambat. $^{15}$

Berdasarkan Peraturan Pemerintah Nomor 48 Tahun 2005 sebagaimana diubah dengan Peraturan Pemerintah Nomor 43 Tahun 2007 tentang Pengangkatan Tenaga Honorer Menjadi Calon Pegawai Negeri Sipil, yang kemudian diubah kembali dengan Peraturan Pemerintah Nomor 56 Tahun 2012 sebagai Perubahan Kedua Peraturan Pemerintah Nomor 48 Tahun 2005, dinyatakan bahwa: "Pengangkatan tenaga honorer yang dibiayai dari APBN dan APBD, dilakukan melalui pemeriksaan kelengkapan administrasi setelah dilakukan verifikasi dan validasi (Pasal 4 ayat (1)). Pada prinsipnya Peraturan Pemerintah Nomor 48 Tahun 2005 melarang adanya tenaga kerja kontrak.

\section{Ad.2. Peningkatan kapasitas dan kualitas SDM}

Proses kegiatan peningkatan kapasitas dan kualitas SDM Aparatur di Pemerintah Kota Surakarta dilakukan melalui pemetaan berbasis kompetensi (talent pool) sehingga dapat menghasilkan ASN yang profesional sebagai salah satu program strategis dalam upaya mewujudkan manajemen ASN berbasis sistem merit. Tahapan pemetaan telah dilakukan sejak tahun 2005 dan saat ini telah selesai. Tahap pertama dilakukan profiling untuk mengidentifikasikan kompetensi melalui assessment center. Tahap kedua adalah penyesuaian penempatan, dan tahap ketiga adalah penempatan. Upaya selanjutnya setelah profiling adalah dengan memisahkan sesuai kompetensi yang dimiliki, dan meningkatkan kompetensi sesuai dengan jabatan yang diduduki,

15 Henny Juliani, https://ejournal2.undip.ac.id/index.php/alj/article/view/5091, Diskresi dalam Rekrutmen Pegawai Non Pegawai Negeri Sipil setelah Pemberlakuan Peraturan Pemerintah Nomor 49 Tahun 2018 tentang Manajemen Pegawai Pemerintah dengan Perjanjian Kerja. 
misalnya pada bidang pekerjaan perencanaan, analisis data dapat ditempatkan pegawai yang cerdas tetapi kurang komunikatif.

Peningkatan kapasitas SDM dilakukan melalui program pendidikan dan latihan, bimbingan teknis, maupun workshop. Hal tersebut dilakukan sebagai sarana dalam pengembangan kompetensi SDM, yang meliputi kompetensi teknis, kompetensi manajerial, dan kompetensi sosial kultural. Kompetensi teknis untuk jabatan pimpinan tinggi, fungsional maupun administrasi yang digunakan untuk peningkatan pekerjaan, kompetensi manajerial meliputi unsur-unsur: integritas, kerjasama, komunikasi, orientasi pada hasil, pelayanan publik, pengembangan diri dan orang lain, mengelola perubahan, dan pengambilan keputusan. Adapun kompetensi sosial kultural menurut kamus kompetensi sosial kultural adalah ASN sebagai perekat bangsa yang dihubungkan dengan peningkatan karakter SDM melalui pemberian motivasi pegawai dengan sarana ESQ maupun melalui motivator.

\section{Ad.3. Penerapan E-Kinerja}

Pemerintah Kota Surakarta telah menerapkan aplikasi E-Kinerja dengan maksud untuk mengoptimalkan pelaksanaan tugas dan fungsi organisasi. Tujuannya adalah: a. Meningkatkan disiplin PNS, kinerja PNS, dan organisasi;b. Meningkatkan motivasi kerja PNS; c. Meningkatkan kesejahteraan PNS. Manfaat yang diperoleh dengan penerapan E-Kinerja adalah:a. Merekam semua aktivitas harian yang dikerjakan oleh PNS; b. Mengetahui optimalisasi kinerja PNS; c. Mengetahui kontribusi PNS terhadap organisasi; d. Mendorong PNS berinisiatif dalam pelaksanaan tugas guna tercapainya tujuan organisasi; e. Sebagai instrumen pemberian tambahan penghasilan bagi PNS sesuai dengan aktivitas/kegiatan yang dikerjakan; f. Sebagai bahan analisa kebutuhan pegawai, evaluasi kinerja pegawai dan bahan pembinaan dan pengembangan pegawai/organisasi; g. Terdapat efisiensi waktu, material, dan SDM.

Yang dimaksud dengan E-Kinerja adalah sistem penilaian kinerja berupa program aplikasi berbasis web oleh Pemerintah Kota Surakarta untuk mengelola beban kerja jabatanpersonil, proses pengumpulan data capaian indikator kinerja dan beban kerja unit/satuan kerja organisasi sebagai dasar perhitungan prestasi kerja serta pemberian insentif kerja.

Indikator penilaian E-Kinerja terdiri dari beberapa komponen yang diharapkan mampu mendorong peningkatan kinerja individu PNS yang berimplikasi terhadap kinerja OPD, antara lain: a. Bobot jabatan dan b. Prestasi kerja. Adapun prestasi kerja terdiri dari 2 (dua) variabel yaitu: a. Prestasi Kerja Individu; b. Prestasi Kerja Perangkat Daerah.

Bobot jabatan pegawai merupakan proporsi pegawai berdasarkan unsurunsur dampak hasil, pekerjaan, wewenang, tanggung jawab, korelasi, ruang lingkup, tingkat kesulitan, dan kompleksitas pekerjaan dengan mempertimbangkan kriteria 
tempat bertugas, kondisi kerja, kelangkaan profesi, dan pertimbangan obyektif lainnya. Bobot jabatan bersifat statis dan memiliki proporsi $40 \%$ dalam penilaian kinerja.

Prestasi kerja individu merupakan kegiatan dari hasil kerja yang dicapai oleh setiap PNS pada satuan organisasi sesuai dengan sasaran kerja pegawai dan perilaku kerja pegawai. Prestasi kerja bersifat dinamis dan memiliki proporsi $60 \%$ dalam penilaian kinerja. Prestasi kerja perangkat daerah merupakan capaian kinerja pelaksanaan APBD pada SKPD yang diukur berdasarkan kualitas dan efektivitas. Adapun indikatornya adalah: a. Aspek kualitas (anggaran) adalah capaian realisasi atau tingkat penyerapan anggaran sesuai dengan rencana; b. Aspek efektivitas (waktu) adalah capaian realisasi atau tingkat penyerapan anggaran sesuai dengan target waktu.

Gambar 2. Kerangka Penilaian E-Kinerja

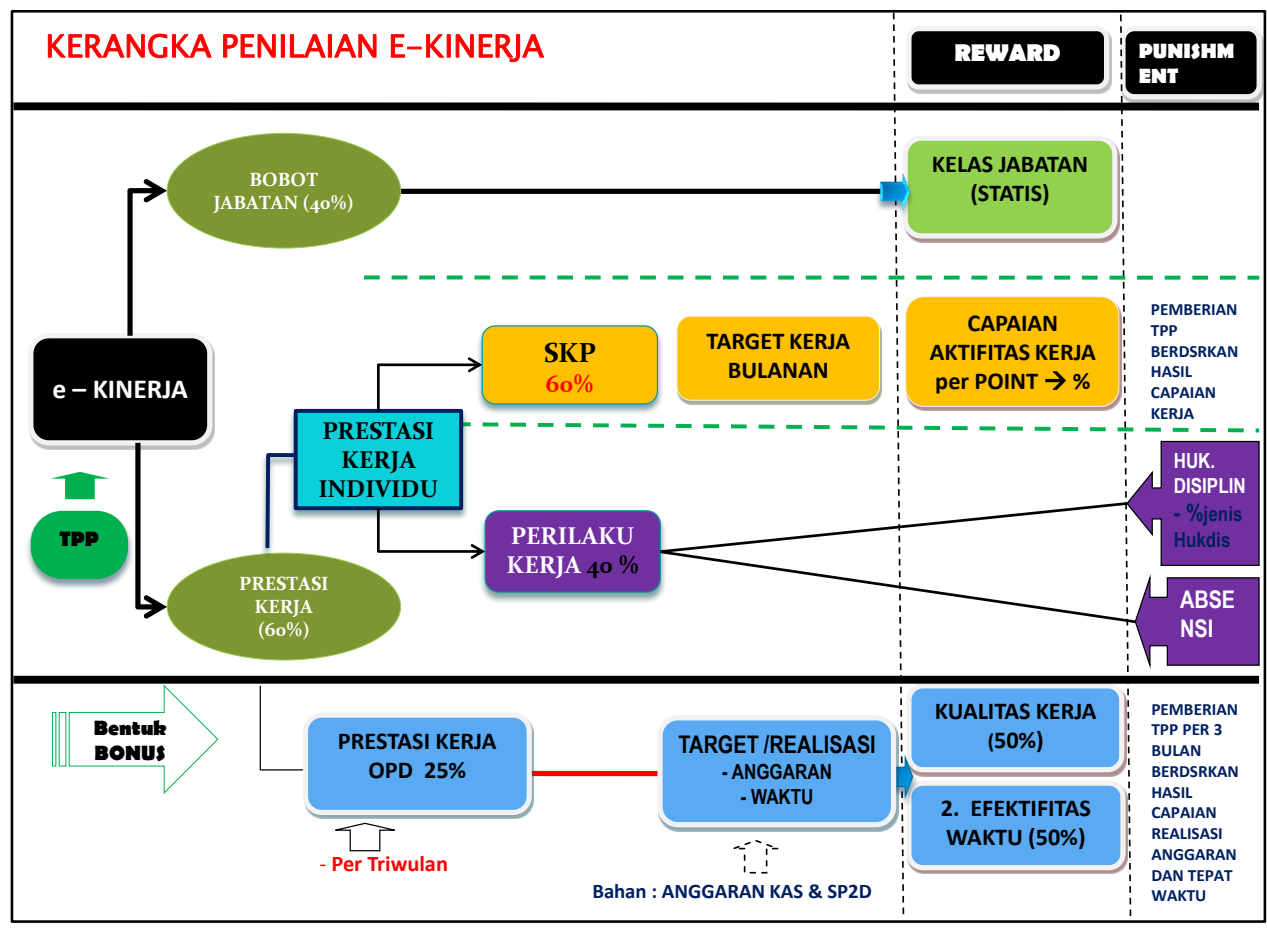

Sumber: BKPPD Kota Surakarta, 2018

\section{Ad. 4. Penerapan Hukuman Disiplin}

Salah satu penilaian prestasi kerja individu adalah perilaku kerja. Perilaku kerja adalah setiap tingkah laku, sikap atau tindakan yang dilakukan oleh PNS atau tidak melakukan sesuatu yang seharusnya dilakukan sesuai dengan ketentuan peraturan perundang-undangan. Perilaku kerja terdiri dari 2 (dua) unsur yaitu hukuman disiplin dan tingkat kehadiran. Perilaku kerja memiliki proporsi $40 \%$ dari unsur prestasi kerja. 
Hukuman disiplin diterapkan berdasarkan Peraturan Pemerintah Nomor 43 Tahun 2010, dengan ketentuan: a. Tidak kena hukuman disiplin, bobot $100 \%$; b. Hukuman disiplin ringan, bobot $90 \%$ (3 bulan); c. Hukuman disiplin sedang, bobot $80 \%$ (6 bulan); d. Hukuman disiplin berat, bobot $50 \%$ (12 bulan). Pengaturan tentang tingkat kehadiran pegawai saat ini masih mengacu pada Peraturan Walikota Surakarta Nomor 5 Tahun 2015 tentang Tambahan Penghasilan berdasarkan Beban Kerja bagi Pegawai di Lingkungan Pemerintah Kota Surakarta. Pengurangan pemberian tambahan penghasilan terdiri dari: a. Tidak masuk kerja; b.Tidak berada di tempat tugas; c. Tidak mengikuti upacara dan apel; d. Terlambat masuk kerja; e. Pulang kerja sebelum waktu.

Terhadap pelanggaran disiplin pegawai, Pemerintah Kota Surakarta telah melakukan deteksi dini early warning system untuk mengidentifikasi ketidakhadiran tanpa keterangan selama 2 (dua) hari berturut-turut sebagai tolok ukur kinerja pegawai dengan tujuan untuk mendisiplinkan pegawai melalui kehadiran. Berkaitan dengan disiplin pegawai, maka aplikasi E-Kinerja dibuat untuk mengatasi belum optimalnya perencanaan kinerja pada tingkat individu atau tingkat unit/organisasi dengan memperhatikan target, capaian, hasil, manfaat yang dicapai dan perilaku PNS. Hal ini juga untuk mengatasi pegawai yang tak berkinerja walaupun dia melakukan finger print pada jam 07.00 dan jam 16.00. Aplikasi E-Kinerja tersebut digunakan untuk mengevaluasi kinerja seorang pegawai dan digunakan juga untuk pemberian reward berupa tambahan penghasilan maupun punishment berkaitan dengan pelanggaran disiplin/hukuman disiplin.

Terdapat beberapa aduan tentang disiplin pegawai, misalnya tentang perselingkuhan antara teman kerja, guru dengan wali murid, dan lain-lain. Termasuk juga dalam kategori tindak pidana ringan, misalnya perjudian, dan tindak pidana berat seperti korupsi (3 orang telah divonis pengadilan). Oleh karena itu berdasarkan statistik PNS Pemerintah Kota Surakarta telah dijatuhkan hukuman disiplin per Oktober 2018 adalah sebanyak 8 (delapan) PNS yang terdiri dari: 3 (tiga) orang dijatuhi hukuman disiplin berat, 2 (dua) orang dijatuhi hukuman disiplin sedang, dan 3 (tiga) orang dijatuhi hukuman disiplin ringan.

Berdasarkan teori yang dikembangkan bahwa indeks profesionalitas ASN merupakan fungsi dari kompetensi, kinerja, gaji, dan disiplin. Premis indikator profesional ASN adalah individu pegawai akan semakin profesional apabila kompetensinya semakin tinggi, kinerjanya semakin meningkat, penghasilannya semakin baik, dan disiplin pegawai yang tinggi. Adapun data-data yang dapat digunakan untuk menghitung indeks profesionalitas ASN berasal dari sumber yang tervalidasi, seperti: Sistem Aplikasi Pelayanan Kepegawaian (SAPK), Pendataan 
Ulang PNS (e-PUPNS), pemetaan PNS, daftar gaji dan tunjangan PNS, Sasaran Kerja Pegawai (SKP), dan data hukuman pegawai. ${ }^{16}$

Untuk mengukur profesionalitas pegawai ASN, maka dikeluarkan PerMenPan dan RB Nomor 38 Tahun 2018 tentang Pengukuran Indeks Profesionalitas Aparatur Sipil Negara. Menurut Pasal 1 angka 4, Profesi merupakan pekerjaan atau jabatan dalam hierarki birokrasi yang menuntut keahlian tertentu serta memiliki etika khusus pada jabatan tertentu. Selanjutnya dalam Pasal 1 angka 5 dinyatakan bahwa profesionalitas adalah kualitas para anggota profesi terhadap profesinya serta derajat pengetahuan dan keahlian yang mereka miliki untuk melakukan tugas-tugasnya. Sedangkan yang dimaksud dengan Indeks Profesionalitas ASN adalah ukuran statistik yang menggambarkan kesesuaian kualifikasi, kompetensi, kinerja, dan kedisiplinan pegawai ASN dalam melaksanakan tugas jabatan (Pasal 1 angka 6).

Pasal 4 PerMenPan dan RB Nomor 38 Tahun 2018 mengatur tentang indikator Indeks Profesionalitas ASN yang diukur dengan menggunakan 4 (empat) dimensi, meliputi: a. Kualifikasi; b. Kompetensi; c. Kinerja; dan d. disiplin.Kualifikasi diukur dari indikator riwayat pendidikan formal terakhir yang telah dicapai, meliputi (Pasal 5) : a.Pendidikan S-3 (Strata-Tiga); b. Pendidikan S-2 (Strata-Dua); c.

Pendidikan S-1 (Strata-Satu) /D-4 (Diploma-Empat); d.Pendidikan D-3 (Diploma-Tiga); e. Pendidikan D-1 (Diploma-Satu) /D-1 (Diploma-Satu)/ SLTA Sederajat; dan f. Pendian di bawah SLTA. Kompetensi diukur dari indikator riwayat pengembangan kompetensi yang telah dilaksanakan yang meliputi (Pasal 6): a. Diklat Kepemimpinan; b. Diklat Fungsional; c.Diklat Teknis; dan d. Seminar/Workshop/Konferensi/Setara.

Kinerja diukur dari indikator penilaian prestasi kerja PNS, yang meliputi (Pasal 7) : a. Sasaran Kerja Pegawai (SKP); dan b. Perilaku kerja. Sedangkan Disiplin diukur dari indikator riwayat penjatuhan hukuman disiplin yang pernah dialami yang meliputi (Pasal 8) : a. Tidak pernah dijatuhi hukuman disiplin; dan b. Pernah dijatuhi hukuman disiplin (ringan, sedang, berat).

Pasal 12 PerMenPan dan RB Nomor 38 Tahun 2018 mengatur tentang Bobot penilaian dimensi Indeks Profesionalitas ASN terdiri atas: a. Kualifikasi memiliki bobot $25 \%$ (dua puluh lima persen); b. Kompetensi memiliki bobot $40 \%$ (empat puluh persen); c. Kinerja memiliki bobot $30 \%$ (empat puluh persen); dan d. Disiplin memiliki bobot $5 \%$ (lima persen).

Berdasarkan hasil perhitungan Indeks Profesionalitas ASN sebagaimana dimaksud dalam Pasal 13, dilakukan pengkategorian tingkat Profesionalitas ASN sebagai berikut (Pasal 14) : a. Nilai 91 - 100 berkategori Sangat Tinggi; b. Nilai 81 -

16 Ajib Rakhmawanto, Op cit 
90 berkategori Tinggi; c. Nilai 71 - 80 berkategori Sedang; d. Nilai 61 - 70 berkategori Rendah; dan e. Nilai 0 - 60 berkategori Sangat Rendah.

Tidak dapat dipungkiri bahwa pegawai yang sudah menjalankan kinerjanya dengan baik berhak atas kompensasi dari kinerjanya tersebut sebagai bentuk penghargaan dan merupakan hak yang harus diberikan oleh pemerintah kepada pegawai tersebut. Kompensasi bisa berupa gaji, tunjangan, dan fasilitas yang diterima pegawai untuk menjamin kesejahteraan pegawai yang bersangkutan. Dengan demikian kompensasi merupakan reward dari kinerja.

\section{Simpulan}

Problem profesionalisme SDM Aparatur dapat dilihat dari kurangnya integritas, rendahnya kompetensi, lambatnya kinerja, dan banyaknya pelanggaran disiplin. Untuk mengatasi hal tersebut, maka Pemerintah Kota Surakarta telah melakukan cara-cara peningkatan profesionalisme SDM Aparatur melalui pendekatan sistem merit dimana profesional mengandung persyaratan kompetensi (Pengetahuan, keahlian, pengalaman), kualifikasi (pendidikan, pelatihan), kinerja (target, pencapaian), kompensasi (kebutuhan, external equity), dan disiplin. Upaya strategis yang dilakukan Pemerintah Kota Surakarta dalam meningkatkan profesionalisme SDM Aparatur telah mengacu pada ketentuan PerMenPan dan RB Nomor 38 Tahun 2018 tentang Pengukuran Indeks Profesionalitas Aparatur Sipil Negara, yang diukur dengan menggunakan 4 (empat) dimensi, meliputi: a. Kualifikasi; b. Kompetensi; c. Kinerja; dan d. Disiplin.

Dengan demikian maka terwujudnya profesionalisme SDM Aparatur akan berdampak pada peningkatan kualitas pelayanan publik, peningkatan kapasitas dan akuntabilitas kinerja birokrasi, dan terwujudnya pemerintahan yang bersih dan bebas dari korupsi, kolusi dan nepotisme. Untuk mewujudkan SDM Aparatur yang profesional perlu dilakukan upaya-upaya yang terus menerus agar dapat mengubah mindset birokrat yang selama ini berkembang sebagai akibat dari pengaruh sikap budaya feodalistik, tertutup, sentralistik, serta adanya arogansi kekuasaan, bahwa birokrat adalah penguasa, lambat, korup, tidak akuntabel, dan lain-lain dalam konotasi negatif dapat diubah dengan menyusun berbagai aturan tentang standar kompetensi, pembinaan integritas dan disiplin, peningkatan kesejahteraan, dan yang terpenting adalah teladan (contoh) dari pimpinan karena itu perlu selalu dilakukan cara-cara peningkatan leadership.

\section{Daftar Pustaka}

Azhar, M., Ispriyarso, B., Sa'adah, N., Suharso, P., Juliani, H., Setyono, J., \& Suparmin, S. (2019). State revenue of the fishery sector after the prohibition policy on illegal unreported and unregulated fishing. In 4th International Conference on Tropical and Coastal Region Eco Development. IOP P Conf. Series: Earth and Environmental Science 246 (2019) 012083. Semarang. doi:10.1088/1755-1315/246/1/012083

Blau, Peter M. dan Meyer, Marshall W., (tanpa tahun) diterjemahkan oleh Gary R. Jusuf, Birokrasi dalam Masyarakat Modern, (Jakarta: UI Press) 
Denim, Sudarwan, 2002, Menjadi Peneliti Kualitatif, (Bandung: Pustaka Setia);

Fuadi, Munir, 2009, Teori Negara Hukum Modern (Rechtstaat), (Bandung: P.T. Refika Aditama)

H.R., Ridwan, 2014, Hukum Administrasi Negara, (Jakarta: P.T. Raja Grafindo Persada)

Juliani, Henny, https://ejournal2.undip.ac.id/index.php/alj/article/view/5091, Diskresi dalam Rekrutmen Pegawai Non Pegawai Negeri Sipil setelah Pemberlakuan Peraturan Pemerintah Nomor 49 Tahun 2018 tentang Manajemen Pegawai Pemerintah dengan Perjanjian Kerja.

Kompas.com, Selasa 18 September 2018

Kusumastuti, Dyah, https://www.researchgate.net/publication/316274009 Manajemen Sumber Daya Aparatur berbasis Kompetensi

Marbun, S.F. dan M.D., Moh. Mahfud, 1987, Pokok-pokok Hukum Administrasi Negara, (Yogyakarta: Liberty)

Peraturan Menteri PAN dan RB Nomor 38 Tahun 2018 tentang Pengukuran Indeks Profesionalitas Aparatur Sipil Negara.

Peraturan Pemerintah Nomor 11 Tahun 2017 tentang Manajemen Pegawai Negeri Sipil;

Peraturan Pemerintah Nomor 53 Tahun 2010 tentang Disiplin Pegawai Negeri Sipil;

Rahayu, Amy Y.S. dan Juwono, Vishnu, 2019, Birokrasi \& Governance Teori, Konsep, dan Aplikasinya, (Depok: Rajawali Pers)

Rakhmawanto, Ajib, Mengukur Indeks Profesionalitas ASN: Analisis Tujuan dan Kemanfaatan, Jurnal Policy Brief Nomor: 006-April 2017 ISSN: 2541-4267.

Undang-Undang Dasar Negara Republik Indonesia Tahun 1945;

Undang-Undang Nomor 5 Tahun 2014 tentang Aparatur Sipil Negara.

Wicaksono, Kristian Widya, 2014, Telaah Kritis Administrasi \& Manajemen Sektor Publik di Indonesia, (Yogyakarta: Penerbit Gava Media) 